\title{
症例報告
}

\section{アダリムマブ投与中にニューモシスチス肺炎を発症した関節リウマチ患者 $\mathbf{2}$ 例の報告 \\ 池 内 秀 和，梅元あずさ，月田真祐子，櫻 井 則 之 \\ 前嶋明人, 黒岩卓, 廣村桂樹, 野島美久 \\ Pneumocystis pneumonia developed in two patients with rheumatoid arthritis during treatment of adalimumab}

\author{
Hidekazu IKeUChI, Azusa Umemoto, Mayuko TsukidA, Noriyuki SAKURAI, \\ Akito Maeshima, Takashi Kuroiwa, Keiju Hiromura and Yoshihisa NoJima \\ Department of Medicine and Clinical Science, Gunma University Graduate School of Medicine
}

(Received May 17, 2011)

summary

While tumor necrosis factor (TNF) inhibitors have dramatically improved the clinical outcomes of rheumatoid arthritis (RA) in recent years, infectious complications are a serious concern. Adalimumab (ADA) is a newly-developed human monoclonal antibody against TNF-alpha. Here we report 2 cases of pneumocystis pneumonia (PCP) which developed in RA patients during ADA therapy. One patient is a 66-year-old woman who had a history of RA for 6 months. The patient was given ADA at $40 \mathrm{mg}$ biweekly for her active arthritis which had been refractory to $6 \mathrm{mg} /$ week of methotrexate (MTX), and $5 \mathrm{mg} /$ day of prednisolone (PSL). One hundred and six days later, she was admitted to our hospital because of fever, cough, and dyspnea. Another patient is a 62-year-old man who had a history of RA for 3 years. Since his arthritis was so active even under the treatment with MTX ( $8 \mathrm{mg} / \mathrm{week})$ and PSL (15 mg/ day), the patient started to be given ADA at $40 \mathrm{mg}$ biweekly. After 28 days, the patient was admitted to the hospital because of dyspnea. Chest roentgenogram and computed tomography revealed interstitial pneumonia in both patients. Beta-D-glucan levels were so high in their serum suggesting the diagnosis of PCP, which was confirmed by the detection of Pneumocystis jirovecii DNA in the sputa by polymerase chain reaction. The patients were immediately treated with sulfamethoxazole/trimethoprim and high-dose prednisolone, which successfully improved pneumonia, and they were discharged from the hospital on the $8^{\text {th }}$ and $16^{\text {th }}$ day, respectively. PCR and $\beta$-D-glucan were useful for the early diagnosis of PCP and lead to the timely induction of adequate treatment and the rescue of these patients.

Key words $\quad$ Rheumatoid arthritis; Pneumocystis pneumonia; Adalimumab

抄録

近年各種 TNF 阻害薬が関節リウマチ（RA）の臨床に導入され，めざましい効果を挙げているが，感染症の合併 も問題になっている．アダリムマブ（ADA）は新規に開発された完全ヒト型抗ヒト TNF 抗体製剤である.今回我 々は ADA 投与中にニューモシスチス肺炎（PCP）を発症したRAの 2 例を経験したので報告する.【症例 1】66 歳女性. RA 罹病期間 5 ヶ月. ADA 開始時, Steinbrocker の病期分類 II, 機能分類 3, DAS28（CRP3）6.18. メ卜 トレキサート（MTX）6 mg/週，プレドニゾロン（PSL） $5 \mathrm{mg} /$ 日を併用していた. ADA は著効し 28 日後には DAS28（CRP3）2.04 になった. 開始 106 日後，38 $\mathrm{C}$ 台の発熱，咳嗽が出現し入院した.【症例 2】62 歳男性. RA 罹病期間 2 年. 既存の肺疾患なし.ADA 開始時, Steinbrocker の病期分類 II，機能分類 3，DAS28（CRP3）6.15. MTX $8 \mathrm{mg}$ /週，PSL $15 \mathrm{mg} /$ 日を併用していた. 関節痛は改善傾向であったが，開始 28 日後，労作時息切れと倦意 感が出現し入院した。両症例とも胸部 CT で間質性陰影を認め， $\beta$-D-グルカン高值であり，PCP と診断した。 入 院同日よりスルファメトキサゾール/トリメトプリム合剂を開始， 70 Torr 以下の低酸素血症があり高用量のPSL も併用した。症状は改善し，それぞれ第 8, 第 16 病日に退院した. 喀痰 Pneumocystis jirovecii DNA は両症例で 陽性であり， $\beta$-D-グルカンと共に早期診断に有用であった。早期に ST 合剤を開始できたことも良好な予後につな がったと考えられた. 
nia : PCP) は, Pneumocystis jirovecii $(\mathrm{Pj})$ によっ て引き起こされる日和見感染症である. HIV 感染 患者では比較的亜急性に発症するのに対し，関節リ ウマチ（RA）を始めとする非 HIV 感染患者に合併 するものは急性に発症し, 重篤で生命の危険を伴う 病態になりかねない1)。近年, RAにおいては TNF 阻害薬が臨床の場に導入され, めざましい効果をあ げている。しかし強力な免疫抑制の結果，PCPの 発症頻度も上昇していることが報告されている2).

アダリムマブ（adalimumab；ADA）は遺伝子組 換えによって作られた初の完全ヒト型抗ヒト TNF モノクローナル抗体製剤である。抗体成分である蛋 白配列が完全ヒト由来であるため, 先行のキメラ抗 体製剤（インフリキシマブ）よりも生体適合性が高 いとされている3).ただし我が国では市販後の日が 浅く, 長期的な治療効果及び安全性データの集積が 待たれている.

今回我々は，RAに対し ADA を投与し PCP を 発症した 2 例を経験した。ADA での PCP 発症は 我々が検索しえた範囲では, 全例調查の中間報告4) の他は症例報告 1 例 $)^{5)}$ しか報告されておらず，その 臨床像をとらえる上で貴重と考えたので報告する.

\section{【症例 1】}

66 歳女性. 既存の肺疾患なく, 2 年前より抗核抗 体陽性を指摘されていたが特に症状なく経過観察さ れていた. ADA 投与 6 ヶ月前より関節痛が出現. リウマトイド因子は陰性であったが左手根骨にびら んを認め RA と診断された. Steinbrockerの病期分 類は II, 機能分類は 3 であった.メトトレキサー
ト（MTX）が開始されたが 3 ケ月後も改善せず， ADA $40 \mathrm{mg} / 2$ 週およびプレドニゾロン (PSL) 5 $\mathrm{mg} /$ 日が投与開始された. 投与開始後 10 日目に細 菌性肺炎の発症がみられたが抗菌薬で改善し, 臨床 症状の改善は続いていたことから ADAの投与は継 続された。導入時の DAS28（CRP3）は6.18であ ったが 28 日後には DAS28 (CRP3) 2.04 と改善が 見られた。 ADA 投与開始 106 日目より $38^{\circ} \mathrm{C}$ 台の 発熱，咳嗽が出現. 111 日目の胸部 Xp $\cdot \mathrm{CT}$ でびま 几性のスリガラス様陰影を認めたため（図 1) 同日 当院入院となった. ADA 投与前および入院時の検 查所見を表 1 に示す.

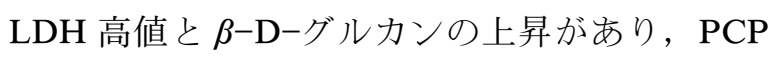
を疑われた。低酸素血症 $(\mathrm{SpO} 293 \%, \mathrm{pO} 2<70$ Torr）も認めたためPSL の増量（60 mg/日）とス ルファメトキサゾール/トリメトプリム合剤（ST 合 剂） $4.8 \mathrm{~g}$ /日の投与が開始された。喀痰からは特に 病原菌になり得る菌は検出されず, 血液培養も陰性 だった，その後入院時の喀痰でPj DNA が PCR で 陽性であることが判明し，PCP の確定診断に至っ た. 症状は改善し, 入院第 16 病日に退院となっ た. 全経過を図 2 に示す。肝機能障害の出現あり ST 合剂は投与 28 日目で中止になっている. 退院後 関節所見の再増悪あり, 退院後 2 ケ月の時点で ADA 再開している. 肝機能障害を考慮し ST 合剂 の予防投与は行っていないが, 現在に至るまで PCP の再発は認められていない.

\section{【症例 2】}

62 歳男性. 既存の肺疾患なし. 4 年前より発熱.
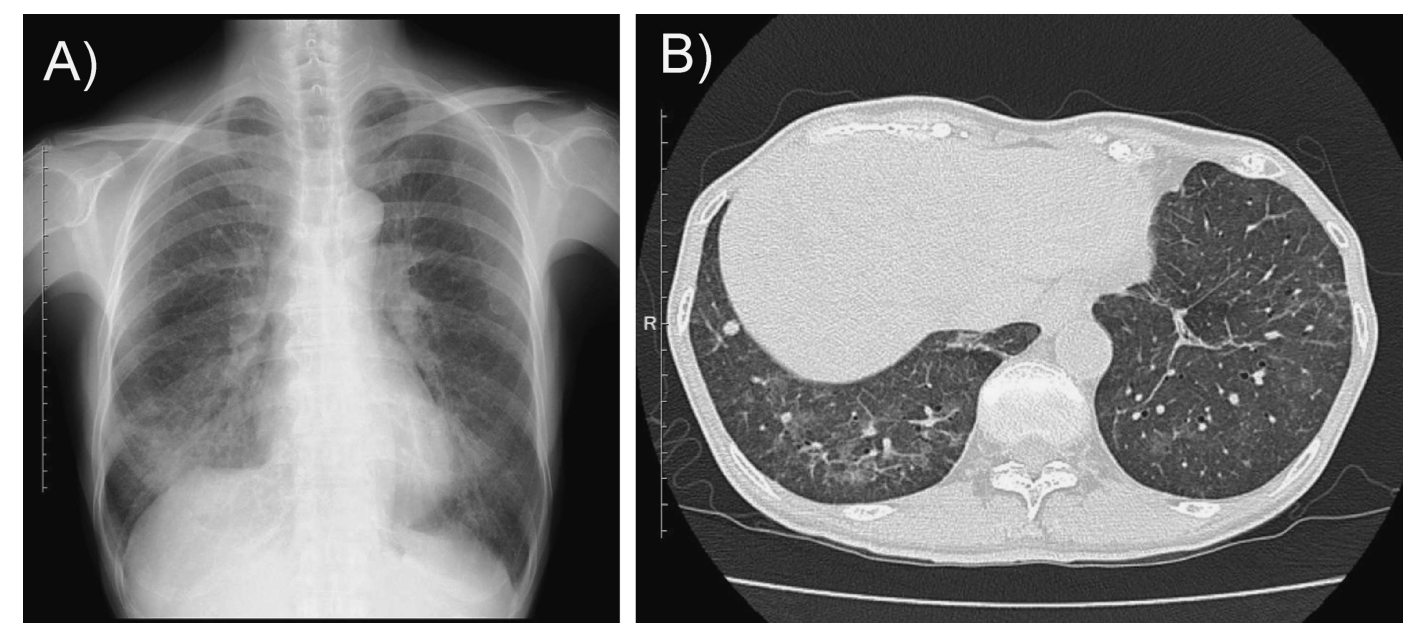

図 1 症例 1

A）入院時胸部正面 $\mathrm{X}$ 線写真 両下肺野にびまん性に広がるスリガラス状陰影を認める

B）胸部 CT 全肺野ほぼ均一なスリガラス状陰影を認める 
表 1 症例 1 検査結果

\begin{tabular}{|c|c|c|c|c|}
\hline & & 正常範囲 & $\begin{array}{c}\mathrm{ADA} \\
\text { 開始時 }\end{array}$ & 入院時 \\
\hline $\mathrm{Ht}$ & $\%$ & $35.0-45.0$ & 42.0 & 36.8 \\
\hline $\mathrm{Hb}$ & $\mathrm{g} / \mathrm{dl}$ & $11.8-15.1$ & 13.7 & 12.0 \\
\hline $\mathrm{RBC}$ & $\times 10^{4} / \mathrm{ul}$ & $4.00-5.00$ & 435 & 384 \\
\hline WBC & $/ \mathrm{ul}$ & $4000-9600$ & 17900 & 9700 \\
\hline $\mathrm{Neu}$ & $\%$ & $42.2-73.2$ & 87.2 & 43 \\
\hline Eos & $\%$ & $0.5-7.3$ & 0.4 & 0 \\
\hline Baso & $\%$ & $0.0-1.8$ & 0.1 & 1 \\
\hline Mono & $\%$ & $2.2-8.4$ & 4.0 & 10 \\
\hline Lym & $\%$ & $20.1-47.3$ & 8.5 & 41 \\
\hline PLT & $\times 10^{4} / \mathrm{ul}$ & $16.0-35.0$ & 38.4 & 28.4 \\
\hline ESR $(1 \mathrm{hr})$ & $\mathrm{mm}$ & 20 & 64 & \\
\hline $\mathrm{TP}$ & $\mathrm{g} / \mathrm{dl}$ & $6.3-7.9$ & 6.5 & 6.5 \\
\hline ALB & $\mathrm{g} / \mathrm{dl}$ & $3.5-4.5$ & 3.2 & 3.5 \\
\hline T-bil & $\mathrm{mg} / \mathrm{dl}$ & $0.3-1.2$ & 0.5 & 1.2 \\
\hline AST & $\mathrm{IU} / 1$ & $13-33$ & 20 & 66 \\
\hline ALT & $\mathrm{IU} / 1$ & $6-27$ & 18 & 21 \\
\hline LDH & $\mathrm{IU} / 1$ & $119-229$ & 234 & 465 \\
\hline ALP & $\mathrm{IU} / 1$ & $115-359$ & 183 & 245 \\
\hline$\gamma-$ GTP & $\mathrm{IU} / 1$ & 13 & 50 & \\
\hline CK & $\mathrm{IU} / 1$ & & 94 & 77 \\
\hline UA & $\mathrm{IU} / 1$ & $2.6-5.8$ & 7.9 & 5.6 \\
\hline BUN & $\mathrm{mg} / \mathrm{dl}$ & $8-20$ & 27 & 16 \\
\hline $\mathrm{Cr}$ & $\mathrm{mg} / \mathrm{dl}$ & $0.6-1.0$ & 0.75 & 0.83 \\
\hline $\mathrm{Na}$ & $\mathrm{mEq} / \mathrm{l}$ & $137-145$ & 139 & 139 \\
\hline K & $\mathrm{mEq} / \mathrm{l}$ & $3.5-4.8$ & 4.2 & 4.4 \\
\hline $\mathrm{Cl}$ & $\mathrm{mEq} / \mathrm{l}$ & $100-107$ & 106 & 106 \\
\hline BS & $\mathrm{mg} / \mathrm{dl}$ & $70-105$ & 119 & 79 \\
\hline T-Cho & $\mathrm{mg} / \mathrm{dl}$ & $128-219$ & 239 & 145 \\
\hline $\mathrm{IgG}$ & $\mathrm{mg} / \mathrm{dl}$ & $870-1700$ & & 1187 \\
\hline $\operatorname{Ig} \mathrm{A}$ & $\mathrm{mg} / \mathrm{dl}$ & $110-410$ & & 381 \\
\hline $\operatorname{IgM}$ & $\mathrm{mg} / \mathrm{dl}$ & $35-220$ & & 274 \\
\hline eGFR & & & 81.3 & 52.8 \\
\hline CRP & $\mathrm{mg} / \mathrm{dl}$ & $<0.1$ & 4.93 & 1.53 \\
\hline$\beta$-D-glucan & $\mathrm{pg} / \mathrm{ml}$ & $<3.1$ & $<3.1$ & 16.4 \\
\hline Quantife ron & & negative & negative & \\
\hline $\mathrm{KL}-6$ & $\mathrm{U} / \mathrm{ml}$ & & & 632 \\
\hline $\mathrm{SP}-\mathrm{A}$ & $\mathrm{U} / \mathrm{ml}$ & & & 93.4 \\
\hline SP-D & $\mathrm{U} / \mathrm{ml}$ & & & 1130 \\
\hline \multicolumn{5}{|l|}{ BGA } \\
\hline $\mathrm{pH}$ & & & & 7.449 \\
\hline $\mathrm{pCO} 2$ & $\mathrm{mmHg}$ & & & 30.8 \\
\hline $\mathrm{pO} 2$ & $\mathrm{mmHg}$ & & & 69.5 \\
\hline $\mathrm{HCO}_{-}^{-}$ & $\mathrm{mmol} / \mathrm{L}$ & & & 22.6 \\
\hline $\mathrm{BE}$ & $\mathrm{mmol} / \mathrm{L}$ & & & -2.2 \\
\hline $\mathrm{SaO} 2$ & $\%$ & & & 94.0 \\
\hline
\end{tabular}

全身関節痛・サーモンピンク疹・白血球増多・肝障 害が出現した。リウマトイド因子も58 と高值では あったが，フェリチン值 $656 \mathrm{mg} / \mathrm{dl}$ と上昇もあり, 成人スティル病と診断された。 PSL 投与にて加療 され症状は改善していたが，PSL $10 \mathrm{mg} /$ 日への減
表 2 症例 2 検査結果

\begin{tabular}{|c|c|c|c|}
\hline & & $\begin{array}{c}\mathrm{ADA} \\
\text { 開始時 }\end{array}$ & 入院時 \\
\hline $\mathrm{Ht}$ & $\%$ & 43.2 & 42.2 \\
\hline $\mathrm{Hb}$ & $\mathrm{g} / \mathrm{dl}$ & 14.4 & 14.0 \\
\hline $\mathrm{RBC}$ & $\times 10^{4} / \mathrm{ul}$ & 444 & 438 \\
\hline WBC & $/ \mathrm{ul}$ & 16200 & 13300 \\
\hline $\mathrm{Neu}$ & $\%$ & 89.2 & 87.5 \\
\hline Eos & $\%$ & 0.4 & 0.1 \\
\hline Baso & $\%$ & 0.1 & 0.1 \\
\hline Mono & $\%$ & 3.6 & 2.2 \\
\hline Lym & $\%$ & 6.7 & 9.8 \\
\hline PLT & $\times 10^{4} / \mathrm{ul}$ & 42.3 & 38.4 \\
\hline TP & $\mathrm{g} / \mathrm{dl}$ & 7.4 & 5.9 \\
\hline ALB & $\mathrm{g} / \mathrm{dl}$ & 3.6 & 2.6 \\
\hline T-bil & $\mathrm{mg} / \mathrm{dl}$ & 0.5 & 0.5 \\
\hline AST & $\mathrm{IU} / 1$ & 18 & 43 \\
\hline ALT & $\mathrm{IU} / 1$ & 14 & 32 \\
\hline $\mathrm{LDH}$ & $\mathrm{IU} / 1$ & 198 & 574 \\
\hline ALP & $\mathrm{IU} / 1$ & 187 & 214 \\
\hline$\gamma$-GTP & $\mathrm{IU} / 1$ & 11 & 19 \\
\hline $\mathrm{CK}$ & $\mathrm{IU} / 1$ & 41 & 84 \\
\hline UA & $\mathrm{IU} / 1$ & 6.4 & 7.2 \\
\hline BUN & $\mathrm{mg} / \mathrm{dl}$ & 18 & 23 \\
\hline $\mathrm{Cr}$ & $\mathrm{mg} / \mathrm{dl}$ & 0.74 & 0.96 \\
\hline $\mathrm{Na}$ & $\mathrm{mEq} / \mathrm{l}$ & 139 & \\
\hline K & $\mathrm{mEq} / \mathrm{l}$ & 4.1 & \\
\hline $\mathrm{Cl}$ & $\mathrm{mEq} / 1$ & 104 & \\
\hline BS & $\mathrm{mg} / \mathrm{dl}$ & 143 & 102 \\
\hline eGFR & & 82.9 & 62.1 \\
\hline CRP & $\mathrm{mg} / \mathrm{dl}$ & 8.49 & 5.67 \\
\hline MMP-3 & $\mathrm{mg} / \mathrm{dl}$ & 634.9 & \\
\hline$\beta$-D-glucan & $\mathrm{pg} / \mathrm{ml}$ & $<3.1$ & 34.8 \\
\hline Quantiferon & & negative & \\
\hline $\begin{array}{l}\text { Cytomegalo } \\
\text { virus antigen }\end{array}$ & & & negative \\
\hline \multicolumn{4}{|l|}{ BGA } \\
\hline $\mathrm{pH}$ & & & 7.428 \\
\hline $\mathrm{pCO} 2$ & $\mathrm{mmHg}$ & & 33.1 \\
\hline pO2 & $\mathrm{mmHg}$ & & 63.8 \\
\hline $\mathrm{HCO}^{-}$ & $\mathrm{mmol} / \mathrm{L}$ & & 22.5 \\
\hline $\mathrm{BE}$ & $\mathrm{mmol} / \mathrm{L}$ & & -2.2 \\
\hline $\mathrm{SaO} 2$ & $\%$ & & 91.8 \\
\hline
\end{tabular}

量と共に両手・右膝関節痛の再出現あり。軽減しな いため 2 年前に右膝関節の MRI を施行したところ 滑膜増殖所見を認めた。発熱，肝機能障害，フェリ チン值の上昇などはなく，成人スティル病から RA に移行したものと考えられた．ブシラミン， MTX を投与されたが効果に乏しかった. PSL も $10 \mathrm{mg} /$ 日前後で経過を見ていたが疼痛の悪化あり $15 \mathrm{mg} /$ 日に増量. Xp 上骨破壊の進行も認めたため ADA $40 \mathrm{mg} / 2$ 週の投与が追加された。ADA 開始時は 
Steinbrocker の病期分類 II，機能分類 3, DAS28 (CRP3) は 6.15 であった. ADA 開始後関節痛は改 善傾向にあったが，22日目頃より労作時息切れ。 倦点感を自覚. 28 日目に外来受診. 胸部 Xp にて 間質影，CT にて両肺野に広がる地図状スリガラス 様陰影を認め (図 3), 同日入院となった. ADA 投 与前と入院時の検查所見を表 2 に示す.

$\mathrm{LDH}$ 高值・ $\beta-\mathrm{D}-$ グルカン陽性であり, PCP が 疑われたため, $\mathrm{ST}$ 合剤 $4.8 \mathrm{~g} /$ 日の投与を行った。 低酸素血症（SpO2 91\%,pO2<70 Torr）も認めた ため高用量ステロイド剤 $(80 \mathrm{mg} /$ 日）の併用も行 った. 本症例ではその他の肺炎球菌性肺炎・異型肺 炎の可能性も考え, アジスロマイシン, セフトリキ アソンの併用も行っている. 喀痰からは特に病原菌 になり得る菌は検出されなかった。 血液培養は陰性

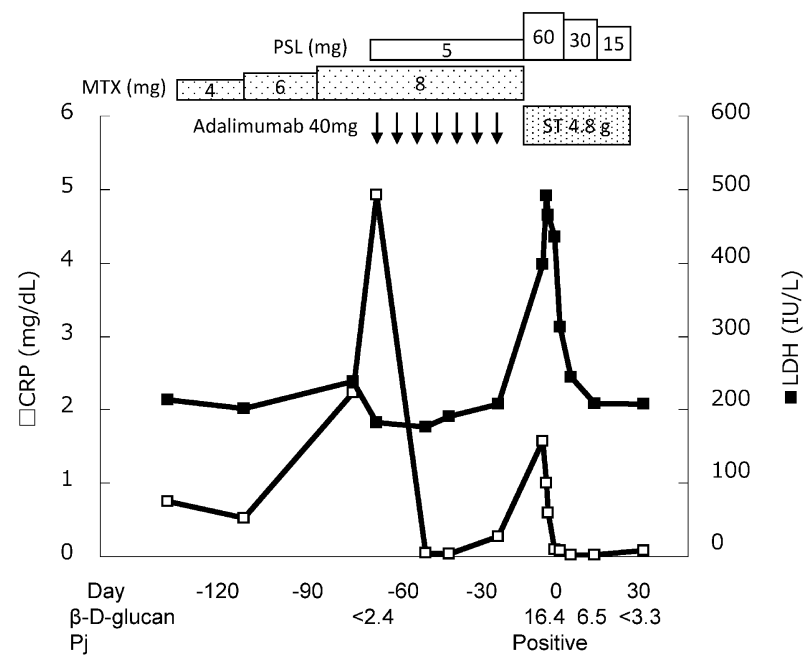

図 2 症例 1 臨床経過

PSL ; プレドニゾロン, MTX ; メトトレキサート, ST ; ST 合剂, $\mathrm{Pj}$; Pneumocystis jirovecii DNA PCR 検査
だった．喀痰から Pj DNA が PCR にて検出され， $\mathrm{PCP}$ の確定診断に至った. ST 合剂以外の投薬は中 止された. 症状改善したため, 入院第 16 病日退院 となった．経過を図 4 に示す．この症例は退院後 4 ヶ月の時点で関節所見の再増悪あり, トシリッマブ を導入したがアレルギー反応の出現のため中止され, 5 ヶ月目より ADA を再開している. 本症例でも ST 合剤の予防投与は消化器症状のため行っていな いが，現在までPCP の再発は認められていない。

\section{考察}

近年各種の生物学的製剤が導入され, RA の治療 は長足の進歩を遂げている. 一方でこうした強力な 治療による副作用の報告も増加している. 中でも PCP は進行が早く重篤化することが多いため, 最

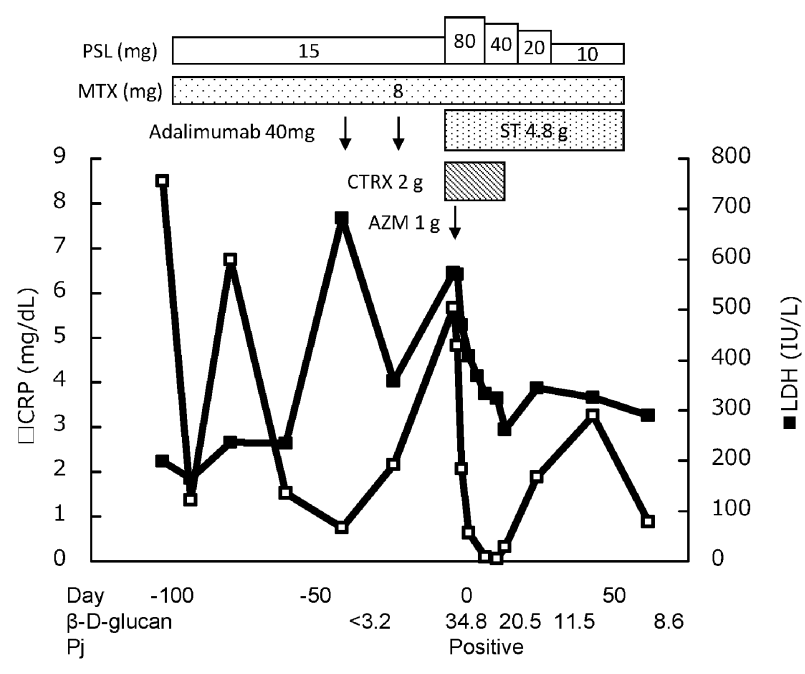

図 4 症例 2 臨床経過

PSL ; プレドニゾロン, MTX ; メトトレキサート, ST ; ST 合剂, $\mathrm{Pj}$; Pneumocystis jirovecii DNA PCR 検査
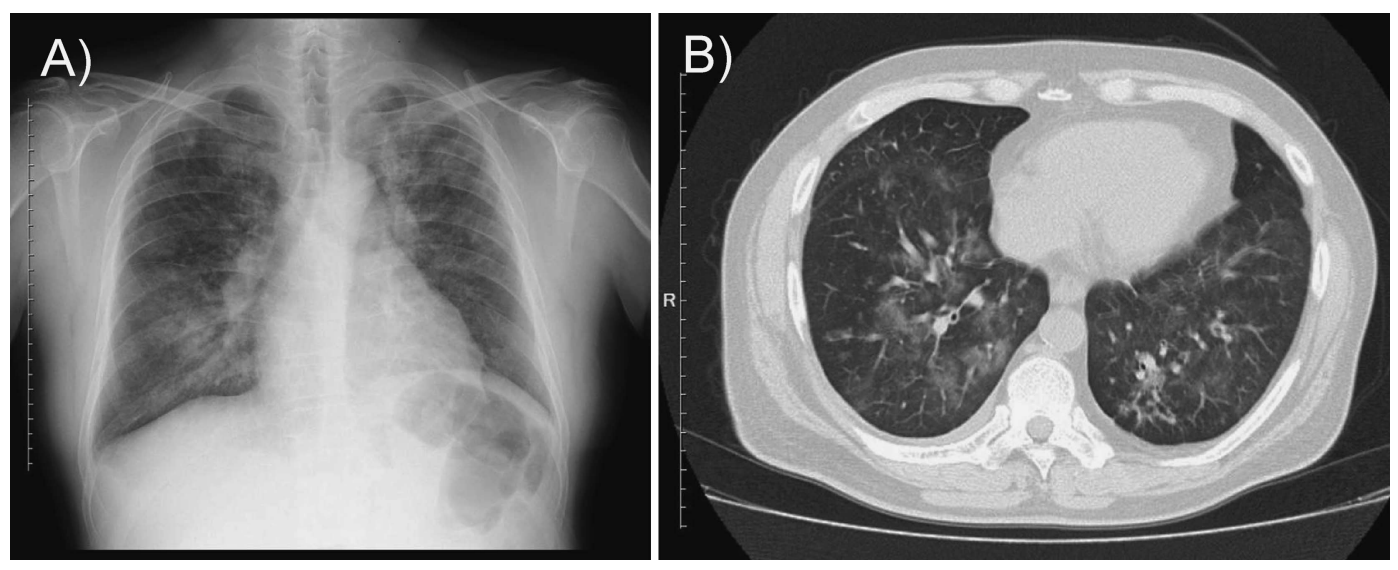

図 3 症例 2

A）入院時正面胸部 X 線写真 両中下肺野にびまん性に広がるスリガラス状陰影を認める.

B） 入院時胸部 CT スリガラス状陰影がモザイク状に分布している. 胸膜直下に正常部分を残している. 
も重要な合併症の一つである11)。しかし ADA にお いては報告例が少なく，その臨床像は不明であ る PCP の特徵について文献的考察を交えながら考察 する.

ADA 治療中に発症した PCP が少数例ではある が報告されている，我が国では RA に対する全生物 学的製剂にて市販後全例調査が行わ扎ており，その 報告によると疑い例も含めた PCP 発症率はインフ リキシマブで 5000 例中 22 例 $(0.4 \%)^{6)}$, エタネル セプトで 7091 例中 16 例 $(0.2 \%)^{7)}$ ，トシリズマブ で 6424 例中 10 例 $(0.2 \%)$ と報告されている ${ }^{8)}$ 。こ れに対し ADA は, 中間報告時点での成績ではある が，7855 例中 27 例 $(0.3 \%)$ となって抢り4), 他の TNF 阻害薬々同様, PCP 発症の危険性がある. イ ンフリキシマブでは欧米に比し我が国での PCP の 発症率が高いと報告されており2), 実際の使用にあ たっては十分注意しながら本剤を使用する必要があ ると考えられる.

ADA におけるPCP 発症の危険因子は定かでは ない.インフリキシマブにおいては我が国の市販後 全例調査を用いた PCP 危険因子の解析が行われて おり, (1)高齢 (65 歳以上), (2)既存の肺疾患, (3) テロイド投与（PSL 換算 $6 \mathrm{mg}$ 以上）の 3 項目が挙

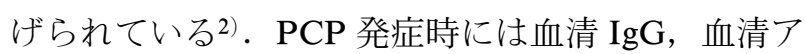
ルブミン值, 末梢血リンパ球数の減少があるとの報 告もある9). 我々の例においては症例 1 では高齢で あり, 発症時の血清 $\mathrm{IgG}$ は $1187 \mathrm{mg} / \mathrm{dl}$ と上述した 報告での PCP 発症群々同程度 (平均 $1192 \mathrm{mg} / \mathrm{dl}$ ) であった。症例 2 では発症時血清 $\operatorname{IgG}$ 值は計測さ れていなかったが，血清アルブミンが $2.6 \mathrm{~g} / \mathrm{dl}$ と低 下して打り $15 \mathrm{mg}$ の PSL 投与も危険因子として当 てはまっていたＡDAに㧤いてもインフリキシマ ブと同様な危険因子が存在していることが予想され る.

どのような症例で ST 合剂投与などの PCP の予 防処置が必要なのかは定かではない。我が国では 2004 年に厚生労働省の研究班が発表した予防投与 基準があるが，RA では実際にこの基準を満たす症 例は少なく10), 我々の症例でも満たしていない。 PCP の予防のためST 合剤を投与することは, AIDS 打よび Wegener 肉芽腫に関しては多くのエ ビデンスがある11,12)。しかし RAに関してはそのよ うなコンセンサスは現時点では存在しない12). ST 合剂の副作用には用量に依存しない重篤なものがあ
り，安易な投与は推奨できない10)。今後の研究およ び確かな予防基準の確立が待たれるところである.

一方で，RA患者で喀痰中の Pj DNA を調べると ある程度の割合で陽性となり, Pjのキャリア症例 と考えられることが報告されている13).こうした症 例では PCP 発症のリスクが高い可能性が考えら れ，このような例に限って ST 合剂の予防投与を行 うことにより，PCPの発生を防止できたとする報 告もある ${ }^{14)}$ ，この報告では ST 合剤の予防投与によ り 1-2 週間で Pj DNA は消失し，そうした例では PCP の発症は認められなかった. Pj キャリア症例 に対する ST 合剤予防投与の妥当性については今後 のさらなる検討が必要である. 一度 Pj を治療し駆 除してしまえばその後は PCP 感染の可能性は低く なるとも考元られる．実際我々の症例は 2 例とも ADA を再投与しているが，現在まで PCP 再発の 所見は認められていない。

TNF 阻害薬の投与から PCP 発症までの期間に関 しては，インフリキシマブ投与 RA 患者で，投与開 始後 6 週以内に 4 割, 14 週以内に約 8 割, 26 週以 内に 9 割と, 大半の症例が投与後早期に発症してい る2). 我々の症例でも ADA 開始後 4 週および 8 週 での発症であり, インフリキシマブと同様の傾向が 認められた。治療開始後早期には関節炎に対する効 果のみならず副作用にも注意して患者の状態をよく 観察する必要性があると考えられた。

RA では疾患自体により間質性肺炎を合併するこ とがあるほか，併用される DMARD（特にMTX） の副作用による間質性肺炎など, PCP との鑑別診 断が問題となる. 我々の症例では ADA 投与前に間 質性陰影はないことを確認しており，経過からも RA によるものは考えにくい. MTX 肺炎の可能性 は考慮に入れ休薬を行っているが（図 2,4), 再開 後も再然がなかったことから考えにくい. 細菌性肺 炎や異型肺炎の可能性に関して症例 2 では抗菌薬の 併用も行ったものの, 痰培養で病因になりうる菌が 検出されなかった点, PCR による Pj DNA 検出が $\mathrm{PCP}$ において特異度が高い点13), ST 合剂投与が著 効した臨床経過から, 本症例における間質性肺炎は PCP によるものと考光るのが妥当であろう.

RA などの非 HIV 患者に打ける PCP は予後不良 の疾患であり，早期治療が予後を決定する鍵とな

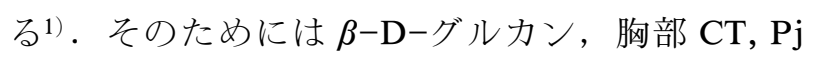
DNA などの検査を遅れることなく実施し, 疑いを 持った時点で PCP として治療を行うことも重要で 
ある. 我々の 2 例においても Pj DNA PCR 検査結 果が不明の段階で本疾患を疑って治療を開始してお り，良好な予後につながった可能性がある。特に上 述した危険因子を有する症例の場合は常に PCP の 発症を念頭に入れて診察する必要があると考えられ た.

$$
\text { まとめ }
$$

ADA に伴うPCP を 2 例経験した。早い段階で の診断と治療により良好な予後を得たが, 診断が遅 れた場合重篤化していた可能性もあった。他の生物 製剂と同様の危険性があることを認識し使用してい く必要がある。

\section{文献}

1) Thomas C. F., Limper A. H.: Pneumocystis pneumonia. $N$ Engl J Med. $350: 2487-2498$, 2004.

2) Harigai M., et al. : Pneumocystis Pneumonia Associated with Infliximab in Japan. $N$ Engl $J$ Med. 357 : 1874-1876, 2007.

3) Weinblatt M. E., et al. : Adalimumab, a fully human anti-tumor necrosis factor alpha monoclonal antibody, for the treatment of rheumatoid arthritis in patients taking concomitant methotrexate: the ARMADA trial. Arthritis Rheum. 48 : 35-45, 2003.

4）アボット株式会社：ヒュミラ適正使用情報； 2010.

5) Kalyoncu U., et al. : Pneumocystis carinii pneumonia in a rheumatoid arthritis patient treated with adalimumab. Scand $J$ Infect Dis. 39 : 475478, 2007.

6) Takeuchi T., et al. : Postmarketing surveillance of the safety profile of infliximab in 5000
Japanese patients with rheumatoid arthritis. Ann Rheum Dis. 67 : 189-194, 2008.

7) Koike T., et al. : Postmarketing surveillance of the safety and effectiveness of etanercept in Japan. J Rheumatol. 36 : 898-906, 2009.

8）中外製薬株式会社：重点調査項目.アクテム ラ点滴静注用 $80 \mathrm{mg}, 200 \mathrm{mg}, 400 \mathrm{mg}$ 安全性 情報全例調查の中間報告. $2010: 21$.

9) Komano Y., et al.: Pneumocystis jiroveci pneumonia in patients with rheumatoid arthritis treated with infliximab : a retrospective review and case-control study of 21 patients. Arthritis Rheum. 61 : 305-312, 2009.

10) Minowa K., et al. : Examination of availability of the criteria for protective therapy against Pneumocystis pneumonia. Nihon Rinsho Meneki Gakkai Kaishi. 32 : 256-262, 2009.

11) Benson C., et al. : Treating opportunistic infections among HIV-exposed and infected children : recommendations from $\mathrm{CDC}$, the $\mathrm{Na}$ tional Institutes of Health, and the HIV Medicine Association of the Infectious Diseases Society of America. MMWR Recomm Rep. 5.3 : 1112, 2004.

12) Green H., et al. : Prophylaxis of Pneumocystis pneumonia in immunocompromised non-HIVinfected patients : systematic review and metaanalysis of randomized controlled trials. Mayo Clinic proceedings. 82 : 1052-1059, 2007.

13) Lu J. Comparison of six different PCR methods for detection of Pnumocystis carinii. J Clin Microbiol. 33 : 2785-2788, 1995.

14) Mori S., et al. : A Followup Study of Asymptomatic Carriers of Pneumocystis jiroveci During Immunosuppressive Therapy for Rheumatoid Arthritis. J Rheumatol. 36 : 1600-1605, 2009. 